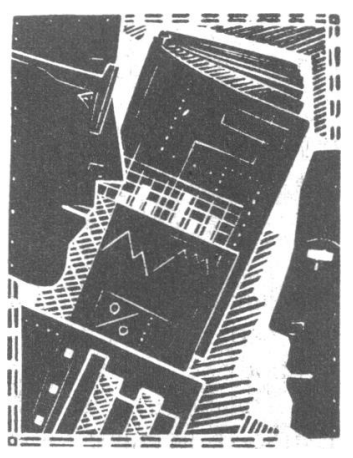

Department of Genitourinary Medicine, Middlesex Hospital, London W1N 8AA

$\mathrm{N}$ Bhatti, MRCP, registrar M P Matthews, MB, senior house officer

Academic Department of Genitourinary Medicine, University College and Middlesex School of Medicine, London W1N 8AA

R J C Gilson, MRCP, senior lecturer

M Beecham, SRN, research nurse

$\mathrm{P}$ Williams, MSC, statistician I V D Weller, FRCP, reader

Division of Virology, Department of Medical Microbiology, University College and Middlesex School of Medicine, London WC1E 6BT

R S Tedder, MRCPATH, professor

Correspondence and requests for reprints to: $\mathrm{Dr}$ Gilson.

BMF 1991;303:97-101

\title{
Failure to deliver hepatitis B vaccine: confessions from a genitourinary medicine clinic
}

\author{
N Bhatti, R J C Gilson, M Beecham, P Williams, M P Matthews, R S Tedder, I V D Weller
}

Abstract

Objective-To audit hepatitis B immunisation of homosexual or bisexual men in a genitourinary medicine clinic.

Design-Retrospective case note review of all homosexual and bisexual men presenting to a genitourinary clinic as new patients during 12 months in 1988 and follow up review of notes to May 1990.

Setting-One department of genitourinary medicine, Middlesex Hospital.

Patients -758 homosexual or bisexual men, of whom 207 started a course of hepatitis B vaccine in 1988. Case notes were unavailable for one patient.

Main outcome measures-The proportion of patients screened for hepatitis B virus markers, the proportion of susceptible patients immunised, the proportion completing the vaccine course, and the proportion rendered immune.

Results -25 men had been previously tested for hepatitis markers; of the 732 not previously tested, $440(60 \cdot 1 \%)$ were screened for hepatitis B markers. $207(69 \%)$ of the 300 patients without hepatitis B serological markers started the vaccine course, and $141(68 \%)$ completed it, with $75(84 \%)$ of the 89 tested after immunisation being immune. An estimated $24 \%$ of susceptible new patients were rendered immune as a result of the immunisation policy. Patients who presented with a further episode of a sexually transmitted disease were more likely to have been screened $(25 \% v 12 \%, \mathbf{p}<0.0001)$ and immunised $(31 \% v 18 \% \mathrm{p}=0.02)$; those known or found to be positive for HIV antibody were more likely to have been screened $(23 \% v 14 \%, \mathrm{p}=0.047)$ but less likely to have been immunised $(6 \% v 17 \%$, $\mathrm{p}=0.004$ ).

Conclusions-The major failure was that in not screening; failure to immunise patients found to be susceptible and failure of compliance with the vaccine course contributed. Non-response to the vaccine was of minor importance. Improvements in vaccine delivery are required.

Implications-Other providers should be encouraged to review their performance.

\section{Introduction}

Homosexual and bisexual men attending genitourinary medicine clinics have a high prevalence of serological markers of hepatitis B virus infection. Acute or chronic current infection, determined by the presence of hepatitis B surface antigen in serum, has been found in $4-10 \%$ of such patients, and $40-70 \%$ have markers of past exposure. ${ }^{1.7}$ In 1987, $48 \%$ of serum samples from homosexual and bisexual men attending this clinic contained evidence of past or present infection with hepatitis $B$ virus, determined by the presence of antibody to hepatitis B virus core antigen. ${ }^{89}$

An effective plasma-derived vaccine to hepatitis $B$ surface antigen became available in 1982 and was followed by recombinant vaccines expressed in yeast. ${ }^{10-12}$ An analysis in the United States indicated that immunisation of homosexual men would result in a reduction in health care costs, ${ }^{13}$ and a similar projection in the United Kingdom showed that it would also be cost effective because of a reduction in health care costs and other costs related to acute hepatitis. ${ }^{14}$

In the United States immunisation has been recommended for all homosexual men, regardless of age or duration of homosexual practices. ${ }^{\text {I5 }}$ In the United Kingdom the Department of Health recommends that immunisation be considered for subjects who frequently change sexual partners, particularly those who are prostitutes or homosexual men. ${ }^{16}$ Despite this recommendation a postal survey of genitourinary medicine clinics in the United Kingdom in 1988 showed that many did not routinely screen for hepatitis $B$ virus infection and that only $30 \%$ offered immunisation. ${ }^{17}$ There has been no report from a genitourinary medicine clinic of the effectiveness of an immunisation policy, where such a policy exists.

We carried out an audit of hepatitis B immunisation by reviewing the case notes of homosexual and bisexual men attending a genitourinary medicine clinic. Its aims were to determine the proportion of patients being screened for hepatitis B markers and, when shown to be susceptible, the proportion completing a course of immunisation with consequent seroconversion for antibody to hepatitis B virus surface antigen.

\section{Patients and methods}

The period of audit was the 12 months of 1988 , chosen as the most recent year which allowed an adequate period for all patients starting the immunisation course to complete it. Data were collected on all patients up to May 1990. Of 235 patients who started a course of hepatitis B vaccine in 1988, $227(97 \%)$ were homosexual or bisexual men, of whom 207 (91\%) first presented to the clinic that year and were therefore new patients. Analysis was restricted to these new patients, who were compared with all 551 other homosexual or bisexual men who were new patients in 1988. The notes of all 758 patients, including those receiving vaccine were reviewed. The following data were extracted from the clinic notes: age, nationality, additional risk factors for hepatitis B infection, hepatitis B serological test results and immunisation record, tests after immunisation, any record of HIV serological tests and status, and current and past sexually transmitted diseases and number of subsequent presentations when one or more sexually transmitted disease had been diagnosed, up to May 1990.

During the study period it was the recommended practice of the clinic that homosexual or bisexual men should be offered screening for serological markers of 
hepatitis $B$ virus infection. The tests performed were to detect antibodies to surface and core antigens by "in house" radioimmunoassays ${ }^{1 \times}$ and surface antigen by enzyme immunoassay (Wellcozyme, Wellcome Diagnostics). If the subject was not immune immunisation with a recombinant yeast-derived vaccine $(20 \mu \mathrm{g}$ Engerix B, Smith Kline and French) was recommended, given by injection into the deltoid muscle in the standard three dose schedule $(0$, one, and six months). Repeat serological testing was advised one to two months after completing the course with quantification of surface antibody titre. At the time of their first and second doses patients were invited to self address an envelope for a reminder letter to be sent before the date of their next scheduled dose of vaccine. No further reminders for immunisation or for testing after immunisation were sent.

Comparisons were made between men screened for hepatitis $\mathrm{B}$ virus markers and those who were not and between those who were immunised and those who were not. Additional comparisons were made between those who completed the course of vaccine and those who received only one or two doses. The MannWhitney U test was used for comparisons of continuous variables. $\chi^{2}$ or Fisher's exact test was used to examine the relation between dichotomous variables, and odds ratios with $95 \%$ confidence intervals were calculated

\section{Results}

The 758 new patients reviewed had a mean age of 30 years (SD 9 years) and $634(83.6 \%)$ were residents in the United Kingdom. At presentation a sexually transmitted disease other than hepatitis B or HIV infection was diagnosed in $222(29.3 \%)$, and 355 $(46 \cdot 8 \%)$ had a history of sexually transmitted disease. HIV antibody status was determined in 307 patients at

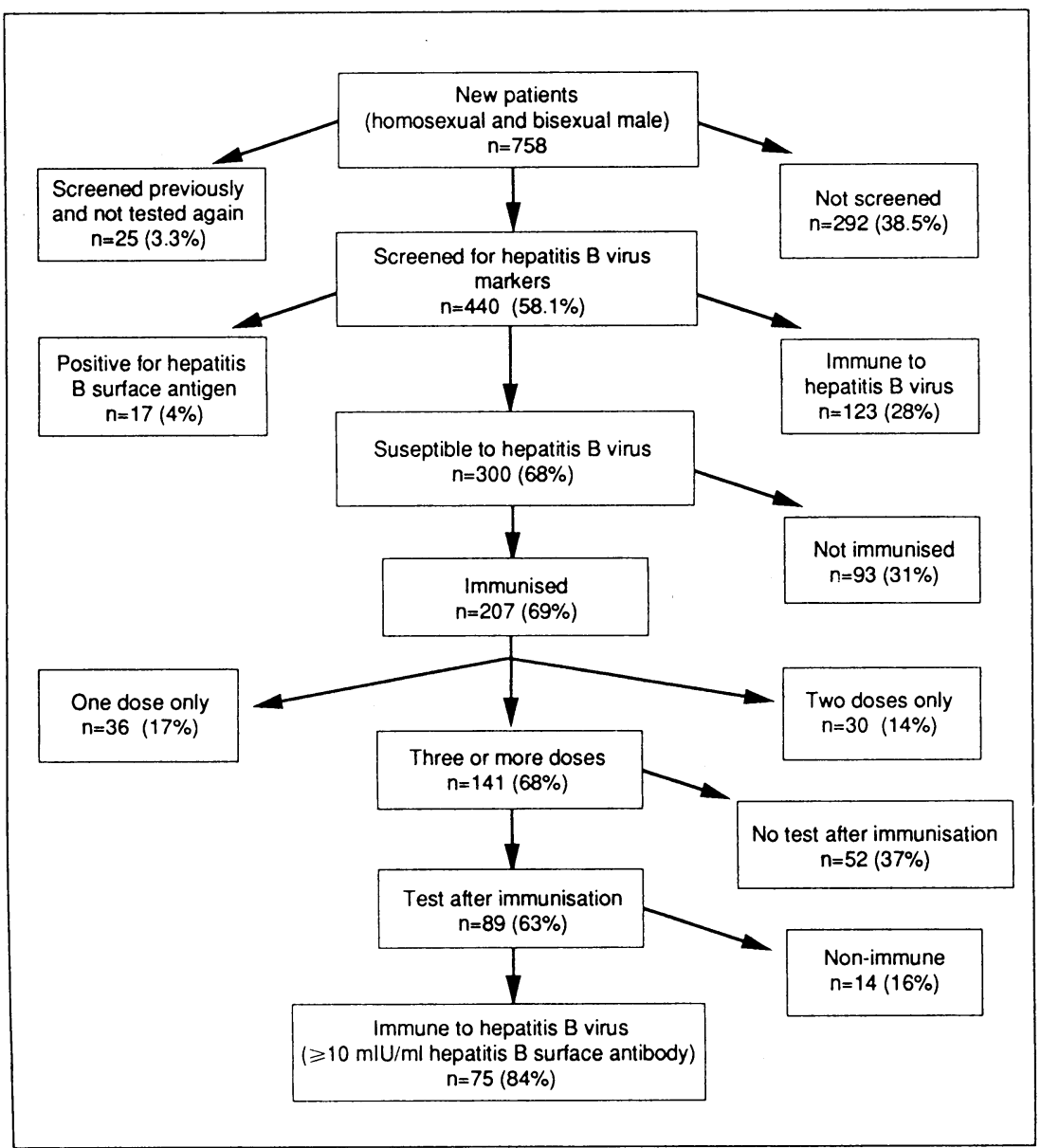

Outcome of hepatitis $B$ virus screening and immunisation policy among homosexual and bisexual men who were new patients in 1988 (data unavailable for one patient)
TABLE I-Intervals between screening before immunisation, vaccine doses, and testing for immunity after immunisation

\begin{tabular}{|c|c|c|c|}
\hline \multicolumn{4}{|c|}{ First clinic attendance to hepatitis $B$ virus test $(n=435)$} \\
\hline Interval (weeks) & $<2$ & $2-12$ & $>12$ \\
\hline No $(\%) \mathrm{men}$ & $372(86)$ & $23(5)$ & $40(9)$ \\
\hline \multicolumn{4}{|c|}{ Test before immunisation to first vaccine dose $(n=201)$} \\
\hline Interval (weeks) & $<4$ & $4-12$ & $>12$ \\
\hline No $(\%)$ men & $168(84)$ & $19(9)$ & $14(7)$ \\
\hline \multicolumn{4}{|c|}{ First to second vaccine dose $(n=163)$} \\
\hline Interval (weeks) & & $6-12$ & $>12$ \\
\hline No $(\%) \mathrm{men}$ & $137(84)$ & $20(12)$ & $6(4)$ \\
\hline \multicolumn{4}{|c|}{ First to third vaccine dose $(n=138)$} \\
\hline Interval (weeks) & $<30$ & $30-52$ & $>52$ \\
\hline No $(\%)$ men & $116(84)$ & $22(16)$ & \\
\hline \multicolumn{4}{|c|}{ Third vaccine dose to test for immunity $(n=88)$} \\
\hline Interval (weeks) & $<8$ & $8-24$ & $>24$ \\
\hline No $(\%)$ men & $40(45)$ & $36(41)$ & $12(14)$ \\
\hline
\end{tabular}

their first clinic attendance or one month afterwards, of whom $80(26 \%)$ were positive; 32 patients were already known to be positive for HIV antibody before attending the clinic. Although not systematically sought, risk factors for hepatitis B in addition to homosexuality were identified in $28(3.7 \%)$ patients.

\section{HEPATITIS B TESTING}

Twenty five $(3 \cdot 3 \%)$ patients were recorded as having been tested previously, and for one patient no information was available. Of those previously tested, eight were immune by natural infection, 10 had been immunised, four were non-immune, and in three their immune state was uncertain. Of the 732 patients not previously tested, $440(60 \cdot 1 \%)$ were tested, most within two weeks (figure and table I). Tests for core antibody or surface antibody, or both, were positive in $140(31 \cdot 8 \%, 95 \%$ confidence interval $27 \cdot 5$ to $36 \cdot 2)$ patients, of whom $17(4 \%$ of those tested, $2 \cdot 1$ to $5 \cdot 7)$ were positive for hepatitis B surface antigen. After excluding those patients previously tested $292(39.9 \%)$ of the 732 patients were not tested, but for only five was it recorded that they had declined; in the remainder the reason was not recorded.

Patients tested for hepatitis B virus markers were younger than those not tested and a greater proportion had presented again to the clinic with a further sexually transmitted disease by the end of the follow up period (table II). This could have been owing to the increased opportunity for testing at subsequent visits; the difference remained, however, when only tests on or within seven days after first attendance were considered. Patients tested for HIV antibody were more likely to be tested also for hepatitis B virus markers. Similarly, patients found to be positive for HIV antibody or already known to be positive were more likely to be tested. There were no significant differences between the two groups with respect to nationality or current or previous sexually transmitted disease.

HEPATITIS B IMMUNISATION

Hepatitis B serological test results were negative in $300(68 \%)$ of the 440 patients tested, of whom 207 $(69 \%)$ started a course of vaccine. No patient was immunised without prior testing. Of the $93(31 \%)$ patients not immunised, $40(43 \%)$ declined, $20(22 \%)$ failed to attend or telephone for results, 23 (25\%) attended but did not receive vaccine for reasons that were not recorded, six (6\%) were given their result by telephone but did not reattend, and four (4\%) preferred to be immunised elsewhere. Patients receiving vaccine were more likely to present again to the clinic with a further episode of a sexually transmitted disease than those who were not immunised (table III). As with screening before immunisation this could have been confounded by the increased opportunity provided by the additional visits to the clinic. This is unlikely, however, because the interval between the date of testing for hepatitis B virus markers and the first dose 


\begin{tabular}{|c|c|c|c|c|}
\hline & Tested & Not tested & $\begin{array}{c}\text { Odds ratio } \\
\text { (95\% confidence } \\
\text { interval) }\end{array}$ & $\mathrm{p}$ Value \\
\hline Mean (SD) age (years) & $29 \cdot 6(9 \cdot 2)$ & $31 \cdot 3(9 \cdot 5)$ & & 0.002 \\
\hline No $(\%)$ of patients with subsequent sexually transmitted disease & $109 / 438(25)$ & $36 / 292(12)$ & $2.36(1.53$ to 3.63$)$ & $<0.0001$ \\
\hline $\begin{array}{l}\text { No (\%) of patients with subsequent sexually transmitted disease (including in the } \\
\text { tested group only those tested within } 7 \text { davs after first attendance) }\end{array}$ & $85 / 3$ & (16) & & $0 \cdot 007$ \\
\hline No $(\%)$ of patients having test for HIV antibody at first attendance (excluding & $05 / 350(24)$ & $0+400(10)$ & $100(1.130240)$ & 0.007 \\
\hline patients already known to be positive) & $181 / 415(44)$ & $91 / 289(31)$ & $1.68(1.21$ to $2 \cdot 34)$ & 0.001 \\
\hline $\begin{array}{l}\text { No }(\%) \text { of patients already known to be positive for HIV antibody or positive on } \\
\text { testing at first attendance }\end{array}$ & $62 / 272(23)$ & $15 / 109(14)$ & $1.85(1.00$ to 3.42$)$ & 0.047 \\
\hline
\end{tabular}

TABLE III -Subsequent sexually transmitted disease, test for HIV antibody, and presence of HIV antibody in patients susceptible to hepatitis $B$ virus receiving or not receiving hepatitis $B$ vaccine

\begin{tabular}{|c|c|c|c|c|}
\hline & Immunised & Not immunised & $\begin{array}{c}\text { Odds ratio } \\
\text { (95\% confidence } \\
\text { interval) }\end{array}$ & $\mathrm{p}$ Value \\
\hline $\begin{array}{l}\text { Mean (SD) age (years) } \\
\text { No }(\%) \text { of patients with subsequent sexually transmitted disease } \\
\text { No }(\%) \text { of patients having test for HIV antibody } \\
\text { No } \% \text { of patients positive for HIV antibody on testing }\end{array}$ & $\begin{array}{l}27 \cdot 2(7 \cdot 6) \\
64 / 207(31) \\
74 / 206(36) \\
7 / 121(6)\end{array}$ & $\begin{array}{l}29 \cdot 6(9 \cdot 3) \\
16 / 88(18) \\
45 / 85(53) \\
9 / 54(17)\end{array}$ & $\begin{array}{l}2.01(1.09 \text { to } 3.73) \\
0.50(0.30 \text { to } 0.83) \\
0.31(0.11 \text { to } 0.87)\end{array}$ & $\begin{array}{l}0.07 \\
0.02 \\
0.007 \\
0.004^{\star}\end{array}$ \\
\hline
\end{tabular}

*With Fisher's exact test.

of vaccine did not differ between those who had a further sexually transmitted disease and thosè who did not $(\mathrm{p}=0 \cdot 35)$. Patients tested for HIV antibody and those found to be infected with HIV were less likely to have been immunised than those not tested or found to be negative for HIV antibody. There were no significant differences between the two groups with respect to age, nationality, diagnosis at presentation, or history of past sexually transmitted diseases.

Of the 207 patients who started a course of vaccine, $141(68 \%)$ completed it; $36(17 \%)$ patients received only one dose and $30(14.5 \%)$ only two doses. Few patients had an appreciable delay between doses (table I). There was a trend towards patients completing the course being more likely to present to the clinic again with an episode of sexually transmitted disease than those not completing it $50 / 141 v 14 / 66$, odds ratio $2.04 ; 0.98$ to $4 \cdot 29$ ). The interval between screening before immunisation and the date of the last dose of vaccine did not differ according to the occurrence of subsequent sexually transmitted disease, and there were no other significant differences between the two groups. Testing after immunisation was performed in $89(63 \%)$ of those who completed the course, with a hepatitis B surface antibody concentration of $\geqslant 10 \mathrm{mIU} / \mathrm{ml}$ detected in $75(84 \%)$ patients, including two patients who had also seroconverted for core antibody due to subclinical infection.

From these data the proportion of all new patients initially susceptible to hepatitis B virus infection who were rendered immune may be estimated. After excluding the few patients already immunised and assuming that the prevalence of markers of hepatitis B infection is the same in patients regardless of testing $499(68 \%)$ of the 732 new patients would have been susceptible to hepatitis B virus infection. Only 141 (28\%) of 499 susceptible patients completed the course of vaccine, and of the $89(63 \%)$ tested after immunisation, $75(84 \%)$ had seroconverted for surface antibody and had a titre of antibody believed to be protective. If a uniform response rate is assumed among those completing a course of immunisation 119 patients were rendered immune, which represents only $24 \%$ of the susceptible population of 499 patients.

\section{Discussion}

We estimated that only about a quarter of homosexual and bisexual men presenting as new patients to a genitourinary medicine clinic and assumed to be sus- ceptible to hepatitis B virus infection were effectively immunised by a course of a recombinant vaccine. This failure to implement the policy of the clinic may be attributed to several factors, which include failure to screen for hepatitis B virus markers, failure to give vaccine to those identified as susceptible, poor patient compliance, and non-responsiveness to the vaccine.

The major failure was in not testing about $40 \%$ of new homosexual and bisexual patients presenting to the clinic. In most cases the reason for this could not be determined by review of the case records, although a few patients had declined or had been tested elsewhere. The prevalence of core antibody of $32 \%$ among those tested and an earlier anonymous seroprevalence study ${ }^{89}$ confirm that this population is at risk of hepatitis $B$ virus infection

The failure to test for hepatitis B virus markers was compounded by a failure to immunise those identified as susceptible, the reason for which in most cases could not be determined from a review of the case notes. Of the patients who commenced the vaccine course, about one third failed to complete it despite a system in the clinic for sending reminder letters. In most of those who did receive vaccine the intervals between testing and vaccine doses were appropriate. Together, the patients who did not complete the course were given $94(17 \cdot 3 \%)$ of the 543 doses of vaccine used, with little likelihood of benefit. The only subgroup of patients showing a trend towards being more likely to complete the course were those reattending with another episode of sexually transmitted disease. By their subsequent clinical history, this subgroup may have shown that they were at highest risk of acquiring hepatitis $B$ virus infection. This risk may have been perceived by doctors at the initial consultation, but the factors influencing them cannot be deduced from this study.

The response rate of $84 \%$ among those tested after immunisation was low compared with that achieved in clinical trials. This may be attributable to the proportion of patients with HIV infection, in whom the response to immunisation is appreciably reduced. ${ }^{19} 20$ This is supported by a simple calculation: assuming, from earlier data on seroprevalence, ${ }^{8}$ an approximate HIV antibody prevalence of $25 \%$ and a vaccine response rate of $50 \%$ among the patients positive for HIV antibody and $95 \%$ among the patients negative for the antibody then the expected response rate in this population is $83.6 \%$, similar to that observed. Although an important issue in future vaccine development, the response rate was a minor consideration 
in the overall efficacy of the immunisation policy. We showed a clear need to improve delivery of hepatitis B virus vaccine to this population. Loke et al showed the wide variation in policy among different genitourinary medicine clinics, although the situation may have improved since their survey was conducted. In the United Kingdom there are no national guidelines for clinical practice in sexually transmitted diseases, such as are produced by the Centers for Disease Control for the United States. ${ }^{21}$ Perhaps more specific recommendations than are provided at present ${ }^{16}$ would improve the provision of this service and the awareness of clinicians. Despite the clear recommendations few homosexual men in the United States have been immunised. $22-24$ Concerns about vaccine cost and safety and lack of health education were seen as having contributed to the failure. Improvement in the provision of the service must be linked with a programme of education of patients and other members of the public at risk. The voluntary organisations Group B and the Terrence Higgins Trust have recently launched such a programme directed at homosexual and bisexual men.

Changes in behaviour that have occurred since the onset of the HIV epidemic may have been responsible for a reduction in the attack rate of hepatitis $B$ virus infection which has been reported. ${ }^{25}{ }^{26}$ However, HIV infection prolongs the period of infectivity of those who acquire the infection by increasing the proportion of those becoming carriers. ${ }^{27}$ There is also a trend towards a lower rate, among carriers, of spontaneous seroconversion from being positive for hepatitis $\mathrm{B}$ e antigen to the less infectious negative state $\mathrm{e}^{2829}$ and a significant reduction in the rate of loss of hepatitis $B$ virus DNA from serum. ${ }^{30}$ HIV infection also diminishes the immunogenicity of the vaccine. In this study patients infected with HIV were less likely to be immunised than the others tested. This may have been because they were erroneously perceived not to be at risk, or not to respond to the vaccine.

The rise in the prevalence of HIV infection and changes in sexual behaviour among homosexual men observed since the analysis of the cost effectiveness of immunisation referred to above ${ }^{14}$ will affect that analysis. The cost effectiveness will have been reduced by the decrease in the response rate to the vaccine among patients positive for HIV antibody and the fall in attack rate but increased by the prolongation of infectivity. Additionally, the original analysis was undertaken when the cost of the vaccine was high, and it excluded the additional costs associated with the late sequelae of persistent infection.

When a policy to screen and immunise is in place an exercise in audit such as that reported here is an essential assessment of clinical performance. The study identified several failures and suggested some solutions, some of which have been implemented. These include a printed reminder of the screening and immunisation policy which has been provided for all clinicians; a checklist has been attached to the syphilis serology proforma as a further reminder. Although routine testing of all patients would increase the effectiveness of screening for hepatitis B markers, the number of unnecessary and repeat tests that would be requested would be unacceptable. Hepatitis B serological tests are therefore still performed only when a request form is completed by the doctor. The need for patients to attend for the results of tests has been emphasised in a patient information leaflet. A few patients might have been immunised if the results of hepatitis B serological testing had been available with other results at the routine one week follow up appointment. The regular reporting of all hepatitis B serological test results within this period has not yet been achieved. As an alternative to the standard
0-1-6 month immunisation schedule, a 0-1-2 month schedule has been suggested, but a booster dose is then recommended at 12 months to achieve equivalent antibody titres and presumed duration of protection. ${ }^{31}$ Patient compliance may be improved by adopting this schedule but no such comparison has been published. A patient recall system is advisable. Our simple recall system could not be readily assessed. In future a computerised system might incorporate sufficient checks to allow an assessment of the recall system. An alternative approach would be to involve the patient's general practitioner. A few patients did opt to go to their general practitioner for immunisation, but many are not registered and others are concerned about confidentiality.

A further dimension to the issues of delivery of hepatitis $B$ vaccine is added by the recommendation now current in the United States that immunisation should be extended to heterosexuals attending clinics for sexually transmitted diseases and reporting multiple sexual partners or with a diagnosis of sexually transmitted disease. Before such a recommendation could be endorsed in other countries, and apart from considering need and cost, the vaccine must be shown to be effectively delivered. We have exposed the poor performance achieved in this clinic in 1988; others are encouraged not to assume that they are doing better.

The help of the late $\mathrm{Dr}$ C H Cameron with the serological assays for hepatitis B virus is gratefully acknowledged. We thank Dr J S Bingham, Professor M W Adler, Dr A Mindel, and Dr D E Mercey, consultants in genitourinary medicine, and $\operatorname{Dr} A M$ Johnson for their help and advice. RJCG was supported by the clinical research and development committee of the University College and Middlesex School of Medicine.

1 Jeffries DJ, James WH, Jefferiss FJG, MacLeod KG, Willcox RR. Australia (hepatitis-associated) antigen in patients attending a venereal disease clinic. BMF 1973;ii:455-6.

2 Fulford KWM, Dane DS, Catterall RD, Woof R, Denning JV. Australia antigen and antibody among patients attending a clinic for sexually transmitted diseases. Lancet 1973; i:1470-3.

3 Coleman JC, Evans BA, Thornton A, Zuckerman AJ. Homosexual hepatitis. f Infect 1979;1:61-6.

4 Ellis WR, Murray-Lyon IM, Coleman JC, et al. Liver disease among homosexual males. Lancet 1979; i:903-5.

5 Hentzer B, Skinhoj P, Hoybye G, Nielsen AO, Kvorning SA, Faber V. Viral hepatitis in a venereal clinic population. Relation to risk factors. Scand $\mathcal{F}$ Infect Dis 1980;12:245-9.

6 Schreeder MT, Thompson SE, Hadler SC, et al. Hepatitis B in homosexual men: prevalence of infection and factors related to transmission. $\mathcal{F}$ Infect $D$ is men: prevalence
1982;146:7-15.

7 Christopher PJ, Mailer PT, Crewe EB, Murphy AM. Hepatitis B infection among STD clinic patients in Sydney. Aust NZ F Med 1984;14:491-4

8 Loveday C, Pomeroy L Weller IVD, et al. Human immunodeficiency viruses in patients attending a sexually transmitted disease clinic in London, 1982-7. in patients attending a sex

9 Gilson RJC, De Ruiter A, Waite J, Loveday C, Kelly G, Weller IVD. Seroprevalence of hepatitis $B$ virus infection in patients attending a genitourinary medicine clinic. In: Piot $\mathrm{P}$, Andre FE, eds. Hepatitis $B:$ a sexually transmitted disease in heterosexuals. Amsterdam: Elsevier, 1990:45-9. (International Congress Series 919.)

10 Szmuness W, Stevens CE, Harley EJ, et al. Hepatitis B vaccine. Demonstration of efficacy in a controlled clinical trial in a high-risk population in the United States. N Engl F Med 1980;303:833-41.

11 Francis DP, Hadler SC, Thompson SE, et al. The prevention of hepatitis B with vaccine. Report of the Centers for Disease Control multi-center efficacy trial among homosexual men. Ann Intern Med 1982;97:362-6.

12 Coutinho RA, Lelie N, Albrecht-Van Lent $P$, et al. Efficacy of a heat inactivated hepatitis B vaccine in male homosexuals: outcome of a placebo controlled double-blind trial. BMF 1983;286:1305-8.

13 Mulley AG, Silverstein MD, Dienstag JL. Indications for use of hepatitis B vaccine, based on cost-effectiveness analysis. $N$ Engl $\mathcal{F}$ Med 1982;307: v44-52.

14 Adler MW, Belsey EM, McCutchan JA, Mindel A. Should homosexuals be vaccinated against hepatitis $\mathrm{B}$ virus? Cost and benefit assessment. $B M \mathcal{F}$ 1983;266:1621-4.

15 Advisory Committee on Immunization Practices. Recommendations for protection against viral hepatitis. MMWR 1985;34:313-34.

16 Joint Committee on Vaccination and Immunisation. Immunisation against infectious disease. London: HMSO, 1988:75.

17 Loke RHT, Murray-Lyon IM, Balachandran T, Evans BA. Screening for hepatitis B and vaccination of homosexual men. BMF 1989;298:234.

18 Tedder RS, Cameron CH, Wilson-Croome R, Howell DR, Colgrove A, Barbara JAJ. Contrasting patterns and frequency of antibodies to the surface, core and $\mathrm{e}$ antigens of hepatitis $\mathrm{B}$ virus in blood donors and homosexual patients. $\mathcal{F}$ Med Virol 1980;6:323-32.

19 Carne CA, Weller IVD, Waite J, et al. Impaired responsiveness of homosexual men with HIV antibodies to plasma derived hepatitis B vaccine. $B M F$ 1987;294:866-8.

20 Collier AC, Corey L, Murphy VL, Handsfield HH. Antibody to human 
mmunodeficiency virus (HIV) and suboptimal response to hepatitis B vaccination. Ann Intern Med 1988;109:101-5.

21 Centers for Disease Control. 1989 sexually transmitted diseases treatment guidelines. MMWR 1989;38(suppl 8):37-8.

22 Centers for Disease Control. Recommendations of the immunization practices advisory committee. Update on hepatitis B prevention. MMWR 1987;36: 353,366

23 Kane MA, Alter MJ, Hadler SC, Margolis HS. Hepatitis B infection in the United States. Recent trends and future strategies for control. Am $\mathcal{f}$ Med 1989:87(suppl 3A):11-3S.

24 McCusker J, Hill EM, Mayer KH. Awareness of use of hepatitis B vaccine among homosexual male clients of a Boston community health center. Public Health Rep 1990;105:59-64.

25 Centers for Disease Control. Changing patterns of groups at high risk for hepatitis B in the United States. MMWR 1988;37:429-37.

26 Polakoff S. Acute viral hepatitis B reported to the Public Health Laboratory Service. F Infect 1990;20:163-8.

27 Taylor PE, Stevens CE, Rodriguez de Cordoba S, Rubinstein P. Hepatitis
$B$ virus and human immunodeficiency virus: possible interactions. In Zuckerman AJ, ed. Viral hepatitis and liver disease. New York: Liss, 1988:198-200.

28 Weller IVD, Brown A, Morgan B, et al. Spontaneous loss of HBeAg and the prevalence of HTLV-III/LAV infection in a cohort of homosexual hepatitis $B$ virus carriers and the implications for antiviral therapy. $f$ Hepato

29 Bodsworth N, Donovan B, Nightingale BN. The effect of concurrent human immunodeficiency virus infection on chronic hepatitis B: a study of 150 homosexual men. F Infect Dis 1989;160:577-82.

30 Krogsgaard $\mathrm{K}$, Lindhardt BO, Nielsen JO, et al. The influence of HTLV-II infection on the natural history of hepatitis $B$ virus infection in male homosexual $\mathrm{HBsAg}$ carriers. Hepatology 1987;7:37-41.

31 Andre FE, Safary A. Summary of clinical findings on Engerix-B, a genetically engineered yeast-derived hepatitis B vaccine. Postgrad Med f 1987;63(supp 2):169-78.

(Accepted 3 April 1991)

\title{
Audit in Person
}

\section{When medical audit starts to count}

\author{
David Bowden, Kieran Walshe
}

Medical audit has been the least controversial element of the NHS reforms. Its widespread acceptance by clinicians has been encouraging, though it is not surprising that organised medical audit is becoming part of everyday practice for the medical profession. Most clinicians have a genuine desire to prove to themselves and to others that they provide a high quality, effective service. That sense of altruism must never be allowed to diminish.

With a few notable exceptions, ${ }^{12}$ however, previous medical audit activities in many hospitals were spasmodic, ad hoc, and uncoordinated. Recent extension and formalisation of audit in most specialties is encouraging because in future medical and clinical audit will be of vital importance to the fate of provider organisations. Whether they succeed or fail will depend not only on their quality of service but also on their ability to prove their effectiveness in terms of outcomes. That is when medical audit will really start to count.

But as medical audit becomes more central to the other major changes in the way the NHS is organised and managed, it in turn will need to be organised differently. There will be an inevitable move towards clinical audit involving other professionals within the clinical team. Medical audit will be more closely linked to risk management. There will be an imperative to relate quality of care with quantity and cost. More explicit quality standards and outcome measures will be specified in contracts between health authorities and their providers. Doctors and managers will be required to share medical audit information within agreed rules of confidentiality, and, generally, managers will want to show the value of their being involved in the audit process. The box outlines the changes in the characteristics of medical audit which are likely to take place.

Up to now managers have largely watched the development of medical audit from the sidelines, partly because of clinicians' sensitivity about the issue and partly because of managers' preoccupations with a wealth of other changes occurring in the past few years. But as medical audit becomes more important to how they manage their organisation, managers will not be content to be spectators; they will want to be players in a genuine partnership with clinical colleagues. They will need to identify what they can and should do to support the audit process and what they will expect and need from audit in the future.
Brighton General Hospital, Brighton BN2 3EW David Bowden, FHSM, district general manager, Brighton Health Authority Kieran Walshe, AHSM, research coordinator, $C A S P E$ Research

Correspondence to: Mr K Walshe, CASPE Research, Department of Public Health.

BMF 1991;303:101-3

\section{Past and future characteristics of medical audit}

\section{Characteristic}

Participation of doctors

Participation of other healthcare professionals

Planning and development Uncoordinated, led by individual of audit systems enthusiasts in data collection interest doctors, lacking comparability
Participation of managers
Entirely voluntary, so dominated by

Limited participation, except perhaps Widespread participation in planning systems

Little management involvement or plans, clinical directorates, and contracting process and collecting and analysing data involved and interested

Coordinated by clinicians and managers. Integrated with general

\section{Future}

Almost compulsory, through peer pressure, job

Audit central to management objectives; managers information strategies

Resources for medical audit Little explicitly allocated-dependent Resources explicitly allocated-both direct and on individual commitment indirect costs recognised

Relevance to organisation's Peripheral to objectives as defined by objectives review process, authority policies, etc

Central to organisation's objectives, as defined by contracting process. Important for organisation's viability/success

Effect on organisation's Little effect on performance - few performance changes in individual or group clinical working practices

Measurable and continuing effect on organisation's performanceclinically and managerially 